\title{
Islamic Economic Thought in the Medieval Times: Some Reflections
}

\begin{abstract}
Nasir Nabi
Abstract

In early Islamic economics, five different dimensions of analysis are broadly identified. First, economic issues have been discussed by Mufassirin in the light of the Holy Quran. For instance, discussions on the prohibition of usury and the encouragement of economic activities for human welfare. Second; economic issues have been discussed in the light of Fiqh. For example the legal aspects of Mudharibah and Musharikah have been dealt within this discipline in great detail. Third; economic matters have been discussed by Muslims in the light of ethical system of Islam for moral development. The works of Ulama, Sufis, Muslim philosophers and reformers come under this category. Fourthly, some good pieces of works, related to economics have been written by some great scholars of Islam in response to the needs of their times while holding important government offices. The works related to public finance, public revenues, land tax, public expenditure fall under this category. The book Kitab al Kharaj by Imam Abu Yusuf is one such example. Finally some Islamic Scholars and philosophers have provided objective analysis in the field of economics. The analysis made by Imam Ghazzali, Ibn Taimiyah, Ibn Khaldun and lately by Shah Waliullah Dehlwi fall under this category.
\end{abstract}

Keywords: Islamic Economic Thought, Abu Yusuf, Abu Ubayd, Al Ghazzali, Ibn Taimiyyah, Ibn Khaldun Shah Waliullah

\section{Introduction}

The economic activities practiced in the early Islamic period had a clear basis in the overall ethical and social philosophy of Islam. It was based on the guidance of Islamic Shariah with the aim of promoting public interests. The general principles were derived from the verses of the Holy Quran and the necessary details and guiding principles were provided by the Prophet $(S A W)$. The economic system at the time of the Prophet $(S A W)$ was not very complex. The Prophet $(S A W)$ lived in the tiny state of Madinah and his economic policies were simple. After his demise (d.632 C.E.) the Islamic state crossed the boundaries of Arabian Peninsula, especially during the reign of Caliph Umar (d. 644 C.E.), this made imperative the need for an organized system which could effectively tackle the new economic challenges. Thus, in the light of the verses of the Holy Quran and Sunnah of the Prophet $(S A W)$, various rules were adopted after mutual consultation (Shura) and consensus (Ijma) of the companions of the Prophet $(S A W)$. The main thrust of the consensus was that policies adopted must be based on the basic principles of Shariah and guided for the public interest. Thus two more sources on Islamic economics were developed besides the Holy Quran and the Sunnah of the Prophet $(S A W)$. These were consensus of opinion and analogical reasoning of experts in Islamic law for the public interest. Afterwards, society expanded and gradually became more complex, newer and newer problems of personal, social, political economic and international nature raised their heads. The need then arose to carry an earnest research to find the solutions of these problems in the light of the Quran and the $\mathrm{Ha}$ dith and so was evolved al-Fiqh. The Fiqh did not remain confined to ablution, fasting, Hajj and Zakat but also encompassed other aspects of society including economics. This state of affairs continued during the period of Khulafa al-Rashidin and Umayyads till the advent of Abbasids, when economic matters were given due importance and were attended with great care. It was in this period that many books on economic matters particularly on financial policy of Islam were written.

The Quran and Hadith being the divine sources have been taken into consideration by Muslim thinkers while discussing the economic matters throughout Islamic history.

\section{Economic Teachings of the Holy Quran}

The Holy Quran provides a series of values, guidelines and rules which serve as the basis for developing an appropriate economic system. Many positive values discussed in the Quran include justice, honesty, moderation and kindness to the disadvantaged whereas injustice, greed, extravagance, miserliness and hoarding are termed as negative values. The Holy Quran permits trade and identifies some prohibited economic practices such as usury, misappropriation and gambling. There are more than two hundred verses in the Quran which in one way or another concern economics; including Zakat, permissible and prohibited goods, wealth, ownership of property, trade, credit and debt, 
fraud, associations and contracts, etc. There are five areas of economic behavior which are prominently mentioned in the Quran. These include Justice and social responsibility, acquisition of wealth, distribution of wealth, the protection of the disadvantaged and regulation of transactions through contracts.

The Holy Quran lays much emphasis upon maintaining justice in society. Justice ( $A d l$ ) is to be upheld in all aspects of life including the economic one. ${ }^{1}$ Those who pursue economic affairs are exhorted to act fairly, truthfully, honestly and in a spirit of co-operation. They are being emphasized to provide a fair description of the goods involved in transaction and ensure that proper standard of measure are used. ${ }^{2}$ Those who commit acts of injustice are required to repent ${ }^{3}$. They are being warned that their punishment in the life hereafter will be severe ${ }^{4}$ and they will have to suffer even in this world. ${ }^{5}$ Many of the prohibited acts in commerce and finance are described as unjust such as dishonesty, cheating, fraud, misrepresentation of things and theft. ${ }^{6}$

Muslim society is held responsible for maintaining economic justice both at individual and collective levels. This responsibility functions through the institution of "Enjoining what is right and forbidding what is wrong." (Al-amr bi-al maruf wa nahi an-al munkar) and is regarded by the Holy Quran as essential to social cohesion. $^{7}$

The Holy Quran highly encourages economic activities and directs Muslims to enjoy fully the bounties of Allah. ${ }^{8}$ The Holy Quran emphasizes repeatedly that all things in the universe belong to Allah. It is $\mathrm{He}$ who created them and allowed man to exploit them and placed them at his disposal. ${ }^{9}$ However, men should distinguish between things lawful and unlawful. The Holy Quran ordains that wealth should be acquired by lawful means only and that unlawful ways and means should be discarded altogether: "O you who believe, take not your wealth among yourselves in wrongful ways, but let there be trade among you by mutual agreement...",10

These "wrongful ways" have been dealt at length by the Holy Prophet $(S A W)$ and the great jurists of Islam have elucidated them in the books of law. Some of them, however, have been described in the Holy Quran as under:

a. "And do not eat one another's property among yourselves in wrongful ways, nor seek by it to gain the nearness of the judges that may sinfully con- sume a portion of other men's goods and that knowingly.", 11

b. "If one of you deposits a thing on trust with another let him who is trusted (faithfully) delivers his trust, and let him fear God, his Lord." 12

c. He who misappropriates (the public money) will come on the Day of Judgment with what he has misappropriated; then shall everyone be given in full, what he earned." 13

d. "The thief, male or female, cut off his or her hands." 14

e. "Those who devour the property of orphans unjustly, devour fire in their bellies, and will soon endure a blazing fire." 15

f. "Woe to the defrauders who, when take the measure from men, exact full measure, but when they measure or weigh for them, give less than is due." $" 16$

g. "Those who love that indecent thing should spread among the believers, for them is a painful chastisement, in the life of this world and the hereafter." 17

h. "Force not your slave-girls to prostitution that you may enjoy (some) gain of the present life, if they desire to live in chastity." 18 And approach not fornication, surely it is shameful deed and an evil way." 19 "The adulterer and the adulteress, flog each of them with a hundred stripes."

i. "O ye believers, wine and gambling and idols and divining arrows are an abomination-of Satan's handiwork; so avoid them that you may prosper." 21

j. " "God has permitted trade and forbidden usury." 22 "O ye believers fear God and give up what remains (due to you) of usury if you are believers (indeed). If you do not so, take notice of war from God and His Messenger. But if you repent you shall have your principal. Neither you wrong, nor shall you be wronged. If the debtor is in straitened circumstance, give him time till it is easy (for him to pay), and that you remit (the debt) by way of charity, that is the best thing for you, if you only knew." 23

Thus, the Holy Qur' an prohibits the following ways of acquiring wealth: taking one's property without consent, bribes, forcible acquisitions, fraud, taking or giving wrong measure, business which spreads indecency, prostitution, manufacturing, buying, selling and carriage of wines, gambling, manufacturing, buying and selling of idols, and business like astrology, foretelling of faith, divination and usury.

The Holy Quran lays down a broader expenditure policy for fair distribution of wealth among the various 
sections of society. The main objective of the Qur'anic principle of distribution is to avoid the concentration of wealth in a few hands. ${ }^{24}$ The Holy Quran repeatedly commands the faithful to give to the poor and needy, ${ }^{25}$ to one's parents and relatives. ${ }^{26}$ Further, it states that the reward for such a deed is great. ${ }^{27}$ It links this giving to belief and warns of severe punishment for those who do not act generously. ${ }^{28}$ Distribution of wealth and prohibition of the concentration are further reinforced by the laws of inheritance that the Holy Quran explains. ${ }^{29}$ Therefore, the Holy Quran wishes that the wealth should always remain in circulation. The Quran criticizes stinginess and miserliness ${ }^{30}$ while moderation is encouraged, ${ }^{31}$ hoarding of wealth is strongly prohibited and those who disobey are warned of hell fire. ${ }^{32}$ Similarly, squandering property is also prohibited; in fact society must prevent individuals from wasting their wealth. ${ }^{33}$ Likewise, extravagance is linked to corruption ${ }^{34}$ with severe punishment to follow. ${ }^{35}$ In the same vein individuals should not spend on prohibited goods or acts such as illicit sex, alcohol or anything that leads to the corruption of society or injury to others.

\section{Economic Teachings of Prophet Muhammad (SAW)}

There are numerous Ahadith, of Prophet Muhammad $(S A W)$ which deal with various aspects of economics. Some of the chief economic issues discussed in hadith include ownership of property, earning one's livelihood, development of land, wages, profit, capital, consumer behavior, market mechanisms, partnerships and business transactions. Most of these ahadith are the explanation of the Qur'anic verses related to economics. Both the Quran and the ahadith provide necessary guidelines and rules which can help in developing an economic system based upon equity and justice.

The Prophet $(S A W)$ actively participated in supervising economic activities in society. He would often visit market places in order to find out the real nature of transactions occurring there. He would advise his companions to be fair while making any business deal.

It is narrated on the authority of Abu Huraira that the Messenger of Allah ( $S A W$ ) happened to pass by a heap of edibles (corn). He thrust his hand (in that heap) and his fingers were moistened. He said to the owner of that heap of eatables (corn). "What is this", He replied, "Messenger of Allah, these have been drenched by rainfall." He (the Prophet) remarked, "why did you not place this (the drenched part of the heap) over the eatables so that the people could see it? He who deceives is not of me (is not my follower). ${ }^{36}$
In another Hadith, Prophet $(S A W)$ has remarked that the defects of goods should be clearly revealed.

Uqba bin Amir reports, I heard the Messenger of Allah saying, "Muslims are brothers to each other. It is not lawful for a Muslim to sell something (to his brother) which contains some defects except what he reveals to him". 37

In fact Prophet $(S A W)$ remarked that one who does not wish for his brother as he wishes for his own self is not a true believer.

It is narrated on the authority of Anas bin Malik that the Prophet $(S A W)$ observed, "No one amongst you believes (truly) till one likes for his brother or for his neighbor what he loves for himself". ${ }^{38}$

Islam guarantees the right to ownership of private property and the Holy Prophet $(S A W)$ has ordained Muslims to safeguard their property. He has also made a distinction between private and public property.

Abu Huraira reports that a person came to the Messenger of Allah and said. "Messenger of Allah, what do you think of a man who comes to me in order to grab my possession?" He said: "Don't surrender your possession to him. He (the inquirer) said: if he fights with me?"He (the Prophet) remarked; then, fight (with him)". He (the inquirer) again said: "what do you think if I am killed? " He (the Prophet) observed: "you will be a martyr." He (the inquirer) said." Messenger of Allah, what do you think of him, (if) I kill him". He (the Holy Prophet) said, "He would be in the fire." 39

In another hadith, Abdullah bin Amir says that the Holy Prophet $(S A W)$ said, "He who dies in protecting his property is a martyr." 40

To prevent cheating, injustice, dishonesty and exploitation, the Holy Prophet $(S A W)$ has forbidden certain unethical trade practices, these practices were prevailing in jahiliya Arabia.

Abu Huraira reports that Allah's Messenger has forbidden (two types of Transactions) Mulamasa and $\mathrm{Mu}$ nabatha. ${ }^{41}$

Abu Huraira also reports that Allah's Messenger $(S A W)$ has forbidden a transaction determined by throwing stones ${ }^{42}$ and the type which involves some uncertainty (Bay al Gharar). ${ }^{43}$

Abdullah Ibn Umar narrates that, Allah's Messenger $(S A W)$ forbade the sale called Habalil-Habala which was a kind of sale practiced in the Jahiliyah period, in which one would pay the price of a she camel which was not born yet, but was likely to take birth. ${ }^{44}$ 
The Qur'anic teachings on economic matters are specific and few in number. The Holy Qur'an mostly gave principles and stressed on the use of mind and application of reasoning. This led to the appearance of a chain of scholars who derived rules to solve new problems and created a juristic logic (usul al fiqh) applicable to a wide variety of social patterns. Their methodology was to refer first to the Holy Qur'an, and practices of the Prophet $(S A W)$, and precedents of his companions and immediate followers who were trained by him. Not finding anything there, they applied analogy and other inferred rules to deduce the Shariah injunctions for the new situation. Gradually, a number of schools of thought in jurisprudence emerged. They were named after their leading scholars and creative thinkers (Imam or Mujtahid), most famous among them are (in chronological order) Zayd bin Ali, Abu Hanifa, Malik, Shafi i A Ahmad bin Hanbal, etc. These schools of jurisprudence were firmly established within a period of less than 300 years after the passing away of the Prophet $(S A W)$. An important reason why masses had faith in them and followed their path is that they were experts of the basic sources of Islam and free from any alien influence. Reflection on economic issues was only one aspect of their pronouncement of rulings over a host of complex problems of life. People addressed them to seek their guidance in their everyday life. If it involved an economic aspect, their analysis used to be economic analysis. There is no doubt that Islamic economic analysis owes a great deal to legal inquiry of this age. ${ }^{45}$

Writings on economic topics and collection of the Prophet's traditions on financial matters started by the end of this phase and in the early period of the next phase by the students of the leading jurists (Imams) and their contemporaries. But due to the nature of their works, they are apt to be considered part of this phase. For example, Abu Yusuf and Muhammad al Shaybani authored Kitab al-Kharaj and Kitab al-Kasb respectively. Yahya b. Adam al-Qurashi compiled traditions of the Prophet related to taxes and other financial obligations, while Abu Ubayd al-Qasim bin Sallam and later his student, Ibn-Zanjawayh, authored Kitab alAmwal. Ibn Abi al-Dunya wrote on Islah al-mal and Abu Bakr al-Khallal on business and economic activities in general. ${ }^{46}$

Muslim economic thinking is distinguished from early economic thought by paying increasing attention to public finance and exclusive writings on the subject. This was but natural in the wake of expanding territory of the Islamic state, availability of new sources of income, confronting new heads of expenditure and facing other socio-economic challenges. Works on taxa- tion in Islam (Kitab al-Kharaj) and public finance (Kitab al-Amwal) first appeared in 2nd/8th century and within the next few centuries more than two dozen treatises were written. The works that could survive include those of Abu Yusuf, al-Qurashi, Abu Ubayd, Ibn Zanjawayh, al-Dawudi, Ibn Rajab, and portions of Qudamah b. Ja`far, and al-Makhzumi. In addition to exclusive works on the subject, issues of public revenue and expenditure constituted parts of juristic and political writings. $^{47}$

\section{Economic Thinking of Eminent Jurists, Sufis and Philosophers up to 450 A.H.}

In this period, economic issues were discussed by $\mathrm{Fu}$ qaha followed by sufis and philosophers. Since the focus of fiqh is what is required by Shari' ah, therefore, the Fuqaha have discussed economic issues in the light of that context only. They have focused upon the principles of permissions (Halal) and prohibitions (Haram) rather than providing descriptions and explanations of economic events in life. Some of the chief economic issues discussed in this period include; Mudaraba, $M u$ sharika, Muzariah, Mulamatha, Munabatha, Bay alGharar, etc.

Some of the important jurists of this period are Zaid $b$. Ali (d.120/738), Abu Hanifa (d.150/767) Awzai (d.157/774), Imam Malik (d.179/798), Abu Yusuf (d.198/798), Muhammad bin Hassan al Shaybani (d.189/804), Yahya bin Adam (d.203/818), Shafi'ee (d.204/820), Abu Ubayd (d.224/838), Ahmad bin Hanbal (d.241/855), Yahya bin Umar(d.289/902), Qudama bin Ja'far (d.337/948), Abu Ja'far al Dawudi (d.402/1012), Mawardi (d.450/1058), Ibn Hazm (d.456/1064), Abu Yala (d.458/1066) and al-Imam alHaramain al Juwayni (d.478/1085).

The sufis have talked about economic life in terms of zuhd (asceticism). They have given less importance to the material world and have focused upon unselfish service to Allah's creatures. Some of the important sufis of this time include Hassan al-Basri (d.110/728), Ibrahim bin Adham (d.161/874), Fudzyl bin Ayad (d.187/802), Maruf Karkhi (d.200/815) and Dhunun Misri (d.245/859).

Among the philosophers, mention may be made of Ibn Miskawiyh (d.421/1030), al-Kindi (d.260/873), alFarabi (d.339/950) and Ibn Sina (d.428/1037).

\section{a. Imam Abu Yusuf (113-182 A.H./731-798 C.E.)}

An emphasis on the economic responsibility of the rulers has been a recurrent theme of Islamic economic thought since the early times of Islam. This happens to 
be the focal point of Imam Abu Yusuf who served as the Chief Justice under the Abbasid Caliph Harun al Rashid. ${ }^{48}$ His book titled Kitab al Kharaj ${ }^{49}$ is written in response to the caliph's queries on the state of religious percepts dealing with taxation problems, revenue administration and public expenditure. He writes, "The commander of the faithful (Amir al Muminin) asked me to prepare for him a comprehensive book to be used for the purpose of the collection of legal taxes, a book for him to study and act upon designed to overt oppression on his subjects and serve their interests". 50

While writing on the subject of revenue collection, Abu Yusuf prefers the state to take a proportional share on agricultural produce from the cultivators rather than levy a fixed rent on agricultural land. This was more just and likely to yield larger revenue by facilitating the expansion of the area under cultivation. Advocating the need for adopting the proportional method, he writes, "In my view the best system of taxation for generating more revenue for the treasury and the most adequate one to prevent injustice to the tax payers by tax collectors is the proportional agricultural tax. This system will alleviate injustice to the tax payers and benefit the treasury." ${ }^{51} \mathrm{He}$ also put emphasis upon the ruler to adopt such policies that could secure the well being of the people and increase the general prosperity and welfare of his subjects. He observes that the work for general utility should be provided publically and free of any direct charge. He holds that all expenses occurring on the provision of public works such as construction of walls, bunds on the river banks to prevent floods and other developmental projects should be borne by the state. For the provision of better irrigation facilities to agriculture, his suggestion to the ruler runs thus. "If these projects are likely to result in improvement and increase in Kharaj, you should order digging of these canals, all expenses are to be met out of the public treasury. Do not charge the expanses from the people of the area because it is better that they should be developed rather than ruined. Every request from the kharaj paying people for repairs etc involving improvements and betterment in their lands and canals should be granted as it does not harm others". ${ }^{52}$ However, if the project is for the benefit of a particular group, in such a case the cost will be properly charged. In regard to the cleaning works on privately owned canals, he recommends, "the whole canal is to be cleared first and expenses should be charged from those who own it, in proportion to their shares in the canal." $^{, 53}$

Abu Yusuf has a detailed discussion on the growth and development of the economy. He suggested various policy measures to be adopted by the state in order to increase the productivity of the land. According to him it is an obligation upon the ruler to arrange for the cleaning of ancient canals and excavation of new ones. He should also construct dams in order to increase the productivity of the land and income of the state. He clearly states, "The expenses of the upkeep of the walls on the river banks to prevent floods and expenses of the dams and of the water locks must be borne by the state treasury and that they should be kept in order, as any malfunction will cause damage to agriculture and decrease the income from taxation." 54

Abu Yusuf provides a detailed discussion on the reclamation of dead and unclaimed land. About the ownership rights of these lands, he holds that he who revives a dead land acquires the right of ownership to it and may continue to cultivate it or let it for cultivation, dig canals in it or otherwise, develop it for his benefit. He will have to pay ushr levy if the land is from ushr category and kharaj levy for kharaj land. ${ }^{55}$ He highly emphasizes upon the cultivation of these lands and categorically recommends that these unused lands must not be kept idle. He holds, "These resources (un owned/waste lands) are like wealth which does not belong to anyone. A just ruler should grant them to someone who promotes the interests of Islam and spends the wealth for a good purpose." 56

\section{b. Abu Ubayd (d.838 C.E.)}

Abu Ubaid's Kitab al Amwal is a comprehensive work on public finance in Islam. ${ }^{57}$ This book is not only a treatise on fiscal system of Islam but it is also a treasure of information concerning laws, history, geography, administration and jurisprudence. The book contains ninety three chapters in total. It is a good source of authentic traditions from the Holy Prophet $(S A W)$ and the reports from his companions, and those who followed them, on economic matters.

While dealing with any issue, Abu Ubayd usually refers to the verses of the Holy Quran, narrates Traditions of the Holy Prophet $(S A W)$ and practices of the pious caliphs and examines their various interpretations, putting out their strength or weakness, then gives his own opinion. While expressing an opinion, he gives reasons for preferring one opinion over the other. Overall the entire book can broadly be divided into two major parts,

Part first starting from item number 1 to 895 deals with revenue that is imposed upon and received from non Muslim citizens of the Islamic state, that is $1 / 5$ th of the spoils of Jizya, Kharaj and different forms of Fay. It 
also discusses the related problems. Part second; (paragraph number 895 to 1988) undertakes Zakat, (the compulsory religious obligation upon the rich Muslims for their poor and needy brethren) and its different forms.

\section{The second phase (450-850 A.H. /1058-1446 C.E.)}

In the second phase of the development of economic thought in Islam, Muslims started with the rich intellectual heritage left by their predecessors besides being directly influenced by the Quran and the Sunnah. At the same time, they faced a political reality characterized by the disintegration of the central Abbasid rule and the division of the Islamic realm into regional powers largely based on force rather than people's consent. There was high level of corruption which was followed by moral disintegration. With the decaying moral fabric of the society, the gap between the rich and the poor was also on an increase. Muslim rulers were less serious in terms of their economic responsibilities towards their subjects. Therefore, they were often reminded of their duties towards their subjects by the Muslim scholars. This age is also characterized by the prosperity of the people with brisk trade practices between the people. People in this age were paying huge taxes and levies to the government with little curb on economic enterprise.

This age, also witnessed a good number of jurists, sufis and philosophers. Some of the noteworthy jurists of this period include; Shamsuddun al Sarakshi (d.483/1090), Nizamul Mulk Tusi (d.485/1093), Imam Ghazzali (d.505/1111), Ibn Mas'ud al Kasani (d.578/1182), Shirazi ,(d.589/1193), Fakhruddin alRazi (d.606/1210), Najmuddi (d.654/1256), IbnTaimiyah (728/1328), IbnUkhuwa (d.729/1329), Ibn al Qayyam (d.751/1350), Muhammad bin Abdur Rahman al Habashi (d.782/1300), Abu Ishaq al-Shatibi (d.790/1388), Ibn Khaldun (d.808/1404) al Maqrizi (d.845/1441).

Similarly, some of the great sufis of this time who also made a deep impact on successive generations of Muslims are al-Qushayri (d.465/857), al-Hujwari (d.490/1096), Abul Qadir Jilani (d.564/1169), Farid aldin Attar (d.622/1252), Ibn Arabi (d.638/1240), Jalaludin Rumi (d.672/1274). This period is also known for its towering philosophers like Ibn Baja (d.533/11380), Ibn Tufayl (d.581/1185), Ibn Rushd (d.595/1198).

All these jurists, sufis and philosophers have touched the economic issues in one way or the other in accordance with their times and situations. However, the present work will only focus upon the few economic insights of Abu Hamid al Ghazaali, Taqiuddin Abul Abbas Ahmad Ibn Taimyah and Ibn Khaldun.

\section{a. Al-Ghazzali (451-505 A.H. /1055-1111C.E.)}

Economic thinking of the author of Ihya-al-ulum al din, ${ }^{58}$ Abu Hamid al- Ghazzali, ${ }^{59}$ is an integral part of his vision of a rejuvenating Islamic life. In his book Ihya al Ulum al din, he devotes a separate chapter for economic teachings of Islam under the title, "Earnings and trade and commerce." ${ }^{60}$ Some of the important economic issues that he discusses in this book include buying and selling, advance payment money, lawful and unlawful ways of earnings, economic justice, economic behaviour and relation between economics and religion. According to Ghazzali, four things are necessary in earnings; earning through lawful means, justice, kindness and fear of religion. ${ }^{61}$ While discussing the principles of buying and selling, Ghazzali observes that no transaction is valid with a minor, insane, slave or a blind man. ${ }^{62}$ However, transaction with the slave becomes lawful with the permission of his master. Similarly, transaction with the blind man is lawful with the consent of his representative. It is also lawful to have transaction with unbelievers but it is unlawful to sell arms to them. ${ }^{63}$

While analyzing the characteristic features of commodities for sale, Ghazzali observes that the things for sale must be fit for transfer and must be known, fixed and certain. The contract for buying and selling must be expressed in clear and unambiguous terms. Intention plays an important part in it and no condition can lawfully be imposed by one party after the agreement is final. ${ }^{64}$

Ghazzali also discusses advance payment of money and things. He observes that the conditions necessary in it are as follows.

1. The quantity and the kind of thing for which advance payment is made should be fixed.

2. The time and place of its delivery should be ascertained.

3. It should not be a precious or a rare thing like a precious jewel.

4. It should be an exchangeable commodity.

5. Its weight and time of delivery must be fixed. ${ }^{65}$

While discussing the prohibition of interest, Ghazzali states that interests arise only in two cases, in transactions of cash money, gold and silver and of food stuffs. Interest occurs in these two cases under two conditions; first sale is held on credit and not in cash; that is not to hand in hand transaction and second, more quantity is taken in lieu of the same kind of things. On account of this, it is unlawful to sell fixed quantity of gold or silver for a fixed quantity of more gold or sil- 
ver. There is however, no fault in selling silver in more quantity in lieu of gold of less quantity, because they are different kinds of things and not of the same kind. It is also unlawful to receive in cash the value of a certain thing which is to be delivered in future. Similarly it is unlawful to exchange food stuffs of the same kind in cash or on credit. For instance, a goat cannot be exchanged with mutton nor can wheat be exchanged with bread. It is also unlawful to exchange milk with milk products. ${ }^{66}$ Ghazzali highly emphasizes upon maintenance of justice in business transactions. He strongly opposes ill economic practices like hoarding and monopolization of wealth. These practices lead market imperfections and hurt the interests of common people. He cites many ahadith of the holy Prophet $(S A W)$ and stories of the pious persons in respect of the prohibition of hoarding. However, he allows, hoarding of such kind of things which are not principle food stuffs for livelihood like saffron and medicines. He also allows hoarding of food stuffs provided their hoarding does not affect the general public. In this way, Ghazzali has provided due regard to the interests of the common people. $^{67}$

Ghazzali regards trade and commerce as a trail for believers. He emphasizes that one should do good to others while pursuing any economic activity. He remarks that one should not make much profit in business and considers it an Ihsan. ${ }^{68}$ However he is not against making much profit. It is better to buy at a higher price from a poor person and while purchasing from a rich person one may search for additional profit. He also regards payment of debt in a good manner as Ihsan. ${ }^{69}$ It is better to go personally and pay the debt than, to wait till it is demanded. He also remarks that one should not forget ones religion and hereafter, while one is in a state of business with others. If he forgets, he will be ruined and will be one of those who sell their next world in lieu of this world. His real capital is his religion and matters relating to the next world. ${ }^{70}$

\section{b. Ibn Taimiyah (661-728 A.H/1263-1328 C.E.)}

Taqiuddin Abu al Abbas Ibn Taimiyah was primarily an author on hadith, but his contribution to Tafsir and Fiqh are no less significant. He also wrote extensively on logic, philosophy, mysticism and comparative religions. His economic ideas are reflected from his works Al Hisbah fi al Islam ${ }^{71}$ (public duties in Islam), Al Siyasah al Shariah fi Islah al Ra'i wal Ra'iyah ${ }^{72}$ (Shariah policies on reforming the affairs of the ruler and the ruled). In his Al Hisbah fi al Islam (public duties in Islam), Ibn Taimiyah envisioned a well provisioned society organized on the basis of freedom of enterprise and private property with limits set by moral considerations and supervisioned by a just ruler enforcing Shariah and working for the welfare of the people. He describes the characteristic features of the Muhtasib in the following words, "The Muhtasib not only ordains the Friday congregation and other communal prayers. $\mathrm{He}$ also exacts truthful reports and the discharge of truths. He proscribes such abominations as lying and deceit, including the giving of small measure and weight and fraudulent practices in history commerce and religious matters etc." 73

In the third chapter of the book, he discusses the issue of price control in detail. He observes that it is wrong to control prices if it involves injury to people and forces them without any justification to sell goods at a price not agreeable to them. He quotes Anas bin Malik (The companion of the Prophet), who narrates, "The market price rose in the time of the messenger of God, on him be peace, and they said to him: Messenger of God; if only you would fix the prices! But he replied: God is The Taker, The Disposer, The Scourer and The Controller of prices. I very much hope that when I meet God, no one will claim against me for an injury, I have caused him in blood and property." miyah however, remarks that if the controlled prices involve just dealings between people and prevents them from doing unlawful activities, then it is not merely permissible but indeed obligatory. For instance, when the owners of merchandise refuse to sell except for more than the reasonable value at a time people are in urgent need or when certain people have monopoly of particular commodities and goods are sold only to them and retailed by them. In these situations, Ibn Taimiyah emphasizes that prices must be controlled, so that people will not suffer. ${ }^{75}$ Another unique contribution of Ibn Taimiyah to Islamic economics is his emphasis upon partnerships based upon proportional shares, for example, one third or one half. To take a fixed amount according to him would not constitute equity but rather injustice. ${ }^{76}$ Ibn Taimiyah also vehemently condemns improper economic practices that involve cheating, fraud or speculation. He quotes many sayings of the Holy Prophet $(S A W)$ against trade practices like Mulamasa, Munabatha and Bay al Gharar. Similarly, he also condemns hoarding and other ill economic practices that lead market imperfections. ${ }^{77}$

\section{c. Ibn Khaldun (732-808/1332-1404 C.E.)}

Ibn Khaldun ${ }^{78}$ was a historian and a social analyst. His Muqaddimah $^{79}$ is one of the greatest works in social, political and economic analysis in the Islamic tradition. Some of the main economic issues that he discusses in 
this book are division of labour, money and prices, production and distribution, international trade, capital formation and growth, trade cycles, poverty and prosperity, population, agriculture, industry and trade and macro economics of taxation and public expenditure. He defines commerce as a means to attempt to make a profit by increasing capital, through buying goods at a low price and selling them at a high price. ${ }^{80} \mathrm{He}$ regards profit as the value realized from human labor. He writes, "The part of the income that is obtained by a person through his own effort and strength is called profit." 81

According to Ibn Khaldun, prices are determined in the market by the interplay of both supply and demand. He writes, "When goods are few and rare, their prices go up, on the other hand, when the country is near and the roadsafe for travelling, there will be many people to transport goods, thus they (goods) will be found in large quantities and the prices will go down." ${ }^{, 2} \mathrm{He}$ regards continued low prices as the main cause of business decline. He writes, "When the prices of any type of goods; food, clothing material or anything else that may bring in capital remain low and the merchant cannot profit from any fluctuation of the market affecting these things, his profit stops, if the situation continues for a long period. Business in this particular line slumps, no trading is done and the merchants lose their capital." ${ }^{, 83}$

Ibn Khaldun observes that the division of labour plays a very important role for growth and development. He observes that civilization and its wellbeing as well as its business propensity depend upon productivity and propelling efforts of people in all directions according to their own interest and profit. The way in which the productive powers of people can be utilized is through cooperation. He notes that production of staple diet like wheat requires six to ten different kinds of services. By coming together to supply all these services, men are able to produce a quantity many times more than the quantity needed for their consumption. ${ }^{84}$ In this way the surplus can be exchanged by the goods produced by others, thus leading to prosperity. He notes that the countries which have a surplus to trade with other countries are more prosperous than the countries that have little to offer for international trade. He observes that more profit can be secured by withholding goods till the market prices are again high and by foreign trade. $^{85} \mathrm{He}$ strongly discourages hoarding. He observes that it can cause loss of profit. He writes, "Intelligent and experienced people in the cities know that it is inauspicious to hoard grain and wait for high prices...the reason may perhaps lie in the fact that people need food and they are forced to spend money on it. For things that are traded other than foodstuffs, people have no compelling need... On things not really needed they spend their money willingly and eagerly and feel no attachment to the money they have spent. ${ }^{86}$

Ibn Khaldun has a wide range of discussion on economic growth. He talks about different types of crafts and their development. According to him crafts can improve and increase only when people demand them. If the demand for a particular craft decreases, the people engaged with that craft become disheartened and their interest decreases, and if the situation continues, this results into the disappearance of that craft. In fact development of civilization and the refinement of crafts are complementary to each other. ${ }^{87}$

\section{The Third Phase (850-1350AH/1445-1932 C.E.)}

As we enter this period, the decline in independent thinking had already yielded to stagnation. But there is a fresh stirring during the last two centuries in which a number of thinkers and reformers called for a return to the Quran and Sunnah for inspiration and guidance. Notable among these are Shah Waliullah (11141176A.H. /1703-1762C.E.), Muhammad bin Abdul Wahab (d.1206A.H. /1787C.E.), Jamaluddin Afghani (d.1294A.H. /1897C.E.), Muhammad Abduh (d.1320A.H./1905 C.E.), Iqbal (d.1356A.H. /1938C.E.).

The jurists in this period were generally speaking content with writing footnotes on the works of their eminent predecessors and issuing fatwa in the light of standard rules of their respective schools. Although the gates of Ijtihad had long been closed, there are numerous insights to be found in the works of jurists like Ibn Nujaym (d. 970/1562) and Ibn Abedin (d.1252/1836).

Similarly, this period also witnessed the works of eminent sufis like Sheikh Ahmad Sirhindi (d. 1034/1624) and a host of other writers. Among all the above mentioned scholars Shah Wali-ullah Dehlvi has significantly contributed in the field of Islamic Economics.

\section{Shah Waliullah (1114-1176 AH-1703-1762 C.E.)}

Economic ideas of Shah Waliullah ${ }^{88}$ are found in different works by him such as Hujjat Allah al-Balighah, al-Budar al-Bazigah, al-Tafhimat al-Illahiyah and his numerous letters that he addressed to different rulers, notables and friends.

Starting from simple primitive village life to an international community, Shah Waliullah divides human society into four stages. These stages he calls the stages of irtifaqat. All his economic ideas are related to 
some way or the other to his concept of Irtifaqat or stages of socio-economic development.

\section{a. Al-Irtifaq al Awwal (The First Stage of Socio- Economic Development)}

In the Irtifaq al Awwal, man becomes acquainted with food stuff suited to his physical constitution and learns how they are to be eaten and digested, besides the ways of preparing and cooking them. He also becomes aware about different methods of cultivation, irrigation, harvest and preservation. He learns how to benefit from animals, their domestication and their use for different works such as ploughing the land, riding over them and benefiting from their milk, meat and wool. He also learns how to manufacture garments out of animal skin. In short this is an age of fulfilling the basic needs of food, shelter and clothing. In this stage the social organization is led by the person who possesses a higher quality of sound judgment and powers to subordinate others. There is a set pattern of rules to resolve the disputes among people. On intellectual level there are people who discover ways of socio-economic development according to their condition and other people become their followers. ${ }^{89}$

\section{b. Al-Irtifaq al Thani (The second stage of Socio- Economic Development)}

In this stage, various occupations of people are agriculture, grazing animals, acquiring natural products of sea and land such as metals, trees, animals; different industries emerge such as carpentry, iron work, weaving, etc. There is division of labour and specialization of work among people. The division of labour arises due to diverse needs of people which they cannot satisfy individually. ${ }^{90}$ The division of labour and specialization may be on the basis of one's ability for doing a particular job or it may be incidental. For instance, the son of a blacksmith takes up iron work. Similarly, the person living close to the sea may take the profession of fishing. ${ }^{91}$ Shah Waliullah emphasizes that one should be very selective in choosing one's job. He should not follow blind tradition of his family. ${ }^{92} \mathrm{He}$ advises municipal authorities that they should be vigilant to people's selection of jobs and should exercise some type of control if necessary to ensure that they do not concentrate on few jobs, leaving others unattended, and to check engagement of more people in production of luxuries and their involvement in socially undesirable production. ${ }^{93}$

Division of labour and specialization lead to the need for exchange which can be done easily through an object that can be used as medium. This leads to the in- vention of money. Thus, it is the second stage of socioeconomic development in which the use of money appears. According to Shah Waliullah, money should be a durable object and commonly accepted by people in their transactions. ${ }^{94} \mathrm{He}$ mentions that of Gold and of Silver are most suitable to be used as money. They are easily divisible into small pieces, their units have similarity, are of great benefit to human physique, and may serve as adoration. ${ }^{95}$

While explaining the rationale of Shariah rules for prohibiting wrong ways of earning wealth, Shah Waliullah particularly takes up gambling and interest. ${ }^{96}$ He notes that gambling amounts to acquiring wealth on the basis of people's ignorance, greed, false hopes and exposure to risks and uncertainties produced by these conditions. Similarly, interest is prohibited because it creates disputes among people and is a source of hatred and envy among them. It also causes decline in agriculture and industry which are fundamental means of earning a living. ${ }^{97}$ Shah Waliullah considers interest in lending as the actual one (al-Haqiqi). He also takes note of barter exchange with inequality in terms of quantity or time of delivery termed as Riba al-fadl and Riba al nasiah in the Shariah. He regards these interests in similitude (Mahmulalaih) ${ }^{98}$ Prohibition of this kind of interest is known by a hadith of the Holy Prophet $(S A W)$ stating that gold for gold, silver for silver, wheat for wheat, barley for barley, dates for dates salt for salt, be exchanged, the same for some, in equal quantity and hand in hand. Incase these groups are different, and then sell them as you like (with unequal quantity). ${ }^{99}$

\section{c. Al Irtifaq al-Thalith (The Third Stage of Socio- Economic Development)}

With the completion of second stage, human society develops into a city stage. Shah Waliullah emphasizes that the city does not mean walls, buildings and market. The city represents relations between different groups of people based on mutual dealings and cooperation. ${ }^{100}$ The integrity, interest and independence of the city are maintained through the Institution of Imam, who acts as a physician to maintain a healthy body of the city. ${ }^{101}$

In this stage, it will be the duty of the government to see that proper allocation of employment is done in different industries and services. Traders and farmers are encouraged in their professions and arrangement for their proper education is also made. He emphasizes that the city develops with easy taxation and employment of necessary number of officials. ${ }^{102}$ 


\section{d. Al-Irtifaq al Rabi (The fourth stage of socio- economic development)}

In this stage the human society and the institution of the government adopts an international character and the need arises to have a government of all the governments (Khalifat al Khulafa). ${ }^{103}$ This is the final stage of socio-economic development. Shah Waliullah does not assign any economic role to the government in this stage, except that it will need a lot of men and material to perform the duty of keeping peace, providing justice and check exploitation.

\section{Conclusion}

Muslims had practical experience of dealing with the economy and state, spread over many centuries. Their ideas bore pragmatic orientation. The scope and subject matter of their economic thinking was not confined to satisfaction, economy of self sufficient household, division of labour, barter and money. They discussed a host of other problems and developed many new ideas. As Muslim scholars based their ideas on both revealed knowledge and human reason, they were more suited to scholastic scholars. In the Islamic tradition two sets of works - al-hisbah and al-siyasah al-shar'iyah - appeared that proved to be a rich source of economic thought of past Muslim thinkers. Works related to alhisbah generally discussed socio-economic control, moral and market supervision, prevention of monopolies, check on cheating and fraud and other such corrupting practices, standardization of products, facilitation of the supply of necessities, etc. As far as works pertaining to al-siyasah alshar'iyah are concerned, they generally deal with the rules of governance, economic role of the state, sources of public revenue, public expenditure (in addition to works exclusively devoted to public finances), maintenance of law and order, internal and external defense etc.

\section{References and Endnotes}

${ }^{1}$ Al Qur'an, 4:58, 6:1523, 11:84, 16:76, 42:15

${ }^{2}$ Ibid, 6:152, 7:85, 11:84-85, 12:59

${ }^{3}$ Ibid, 5:39

${ }^{4}$ Ibid, 39:24

${ }^{5}$ Ibid, 29:21

${ }^{6}$ Ibid, 3:16, 82:1-6

${ }^{7}$ Al Qur'an, 7:152, 9:71

${ }^{8}$ Ibid, $7: 10,7: 32,34: 15$

${ }^{9}$ Ibid, $2: 29,7: 10,13: 3$

${ }^{10}$ Ibid, 4:29

${ }^{11}$ ibid, 2:188

${ }^{12}$ Ibid, 2:283

${ }^{13} \mathrm{Al}$ Qur'an, 3:161

${ }^{14}$ Ibid, 5:41

${ }^{15}$ Ibid, 4:10

${ }^{16}$ Ibid, 83:1-3

${ }^{17}$ Ibid, 24:19

${ }^{18}$ Ibid, 24:33

${ }^{19}$ Ibid, 17:32

${ }^{20}$ Ibid, 24:2

${ }^{21}$ Ibid, 5:93

${ }^{22}$ Ibid, 2:275

${ }^{23}$ Ibid, 2:278-80

${ }^{24}$ Ibid, 2:83

${ }^{25}$ Ibid, 2:271

${ }^{26}$ Ibid, 2:83

${ }^{27}$ Ibid, 92:5-7

${ }^{28} \mathrm{Al}$ Qur'an, 74:42-44

${ }^{29}$ Ibid, 4:7-12

${ }^{30}$ Ibid, 53:33-34

${ }^{31}$ Ibid, 17:29

${ }^{32} \mathrm{Al}$ Qur' an, 9:34

${ }^{33}$ Ibid, 4:5

${ }^{34}$ Ibid, 2:60, 7-74

${ }^{35}$ Ibid, 7:86, 13:25

${ }^{36}$ Imam Muslim, Sahih Muslim, Arabic English, Tr. English, Abdul Hamid Siddiqi, Vol, 1, (New Delhi: Adam Publishers and Distributers, 2006), H. no. 186.

${ }^{37}$ Ibn Majah, Sunan Ibn-e-Majah, Bk.12, (al-Tijarah), CH. 15; Muhammad Akram Khan, Economic Teachings of Prophet Muhammad SAW (Delhi:Noor Publishing House, 1992)

${ }^{38}$ Imam Bukhari, Sahih Bukhari, Arabic English Tr. English, Muhammad Muhsin Khan, (Riyadh: Maktaba Dar al Salam publishers and Distributers, 1994), H. No. 13.

${ }^{39}$ Sahih Muslim, Op.cit., vol.1, H. No.259

${ }^{40}$ Ibid., H. No. 260

41 "Mulamasa", means that a man touches another's garment or cloth or anything else without turning it over and $\mathrm{Mu}$ nabatha, means that a man throws his cloth to another, and the other throws his cloth to the first, thus confirming their contract without inspection or mutual agreement. Sahih Muslim, op.cit.,5, H. no. 1511

${ }^{42}$ This is a type of transaction which was prevalent in the markets of Jahilia Arabia. The transaction was done by throwing a stone either by the seller or by the purchaser 
and whatever the stone touched, its transaction became binding.

${ }^{43}$ Bay al Gharar; one might translate this as arbitrary contact of sales, but this is not the only term to which it is applied. This type of transaction intended, is one in which there is no guarantee that the seller can deliver the goods for which he receives payment. It could include such items as selling a runaway slave or fish which one has not caught.

${ }^{44}$ Sahih Bukhari, Op.cit., H. No. 1022

${ }^{45}$ Abdul Azim Islahi, Contribution of Muslim Scholars to Economic Thought and Analysis, (Jeddah: Islamic Economics Research Centre, King Abdul Aziz University, , 2004), 12

${ }^{46}$ Contribution of Muslim Scholars to Economic Thought and Analysis, Op.cit,13.

${ }^{47}$ Ibid, 61.

${ }^{48}$ Yaqub ibn Ibrahim Abu Yusuf (731-798 C.E.), was a scholar of high degree and served as chief justice under Abbasid Caliph Mahdi (d. 785 C.E.) and his son Harun (d. 809 C.E.)

${ }^{49}$ The book Kitab al Kharaj of Imam Abu Yusuf was first published in 1885 from Cairo-Egypt. It has been translated into English, French, Italian, Turkish and French languages.

${ }^{50}$ Abu Yusuf, Kitab al Kharaj (Beirut: Dar al-M'arifah, 1979), 3

${ }^{51}$ Ibid, 50.

${ }^{52}$ Kitab al kharaj, Op. cit, 109

${ }^{53}$ Ibid, 11.

54 ibid, 110.

55 Ibid., 65.

${ }^{56}$ Kitab al kharaj, Op. cit, 58.

${ }^{57}$ Abu Ubayd al Qasim bin.Sallam (774-838 C.E.) was an eminent scholar of Quran, Hadith and Islamic law. His book is the most comprehensive work on the subject of economics. It contains about two thousand (1998) items on fiscal issues.

${ }^{58}$ Imam Ghazzali, Ihya al-Ulum al Din, Tr. English, Fazlul Karim, (New Delhi:Islamic Book Services 1995).

${ }^{59}$ Abu Hamid b. Muhammad al Ghazzali (1058-1111 C.E) born in Khurasan, is one of the eminent scholars of Islamic Science including logic, philosophy and sufism (mysticism).

${ }^{60}$ Ihya al-Ulum al Din, Op. cit, 45 .

${ }^{61}$ Ibid., 48.

62 Ibid., 49.

${ }^{63}$ Ihya al-Ulum al Din, Op.cit,

${ }^{64}$ Ibid., 50.

${ }^{65}$ Ibid, 51

${ }^{66}$ Ihya al-Ulum al Din, Op.cit. 48.

${ }^{67}$ Ibid., 53.

68 Ibid., 57.

${ }^{69}$ Ibid.,

${ }^{70}$ Ihya al-Ulum al Din, Op.cit, 58.

${ }^{71}$ Ibn Taimiyah, Al-Hisbah, fi al Islam Tr. English Muhtar Holland ed. Khurishid Ahmad, (The Islamic foundation ,1982)
${ }^{72}$ Ibn Taimiyah, Al-Siyasah al Shariah fi Islaha al Rai wa'l Ra'iyah, (Damascus: Maktaba Dar al-Bayan, 1985)

${ }^{73}$ Ibn Taimiyah, al-Hisbah fi al Islam, op.cit. 29.

${ }^{74}$ Abu Daud and al Tirmidhi, Quoted from al-Hisbah fi al Islam op.cit. 35 .

${ }^{75}$ Al Hisbah fi al Islam, op.cit. 36.

${ }^{76}$ Ibid, 40-41.

77 Ibid, 160.

${ }^{78}$ Ibn Khaldun was born in 1332 C.E. in Tunis into an old Arab family of the Hadramout which had emigrated first to Spain, then to Morocco and finally settled in Tunisia. He received a thorough education in the theological and philosophical disciplines, taught at Madrasa of Tunis by outstanding scholars.

${ }^{79}$ Ibn Khaldun, Muqaddimah (An Introduction to History, Tr. English, Franz Rosenthal, ed. N J Dawood, (London: Rout ledge and Paul, 1967).

${ }^{80}$ Muqaddimah, op.cit,. 309

${ }^{81}$ Ibid.

82 Ibid, 310.

${ }^{83}$ Ibid, 311.

${ }^{84}$ Muqaddimah, op.cit, 46

${ }^{85}$ Ibid, 310.

${ }^{86}$ Ibid, 311.

${ }^{87}$ Ibid, 316-317.

${ }^{88}$ Qutub al Din Ahmad b.Abdur Rahim,more commonly known as Shah Waliullah Dehlwi (1702-1763 C.E.), lived during the Mughal rule in India. His economic ideas are mainly reflected from his Hujjat Allah al Baligah. In this work, he explains the rationale of shariah rules for personal conduct and social organization.

${ }^{89}$ Shah Wali Allah, Hujjat Allah al Baligah, Vol.2, (Beirut, Dar al Fikr), 40.

${ }^{90}$ Shah Waliullah, al Budur al Bazighah, al Majlis al IImi, Dabhel, 50.

${ }^{91}$ Hujjatullah Balighah, op.cit., vol. 1, 43

${ }_{92}$ Al-Budur, op. cit., 60.

${ }^{93}$ Hujjatullah Baligah, op.cit, Vol. 2, 105.

${ }^{94}$ Hujjatullah Baligah, op.cit, Vol. 2, 43 .

95 Ibid., vol. 2, 43

96 Ibid., p. 106

${ }^{97}$ Hujjatullah Baligah, op.cit, Vol. 2, 106.

${ }^{98}$ Ibid., 107 .

${ }^{99}$ Imam Bukari, Sahih Bukhari, op.cit.,H. no. 1027-1029

${ }^{100}$ Al-Budur, op. cit, 51

${ }^{101}$ Ibid., 71-72.

${ }^{102}$ Hujjatullah Balighah op. cit 45-47.

${ }^{103}$ Al-Budur, op. cit 85. 


\section{Selected Bibliography}

Muslim, Sahih Muslim, Arabic English, Tr. English, Abdul Hamid Siddiqi, Vol, 1. New Delhi: Adam Publishers and Distributers, 2006.

Akram Khan, Muhammad. Economic Teachings of Prophet Muhammad SAW. Delhi:Noor Publishing House, 1992.

Bukhari, Sahih Bukhari, Arabic English Tr. English, Muhammad Muhsin Khan. Riyadh: Maktaba Dar al Salam publishers and Distributers, 1994.

Islahi, Abdul Azim. Contribution of Muslim Scholars to Economic Thought and Analysis Jeddah: Islamic Economics Research Centre, King Abdul Aziz University, 2004.

Abu Yusuf, Kitab al Kharaj. Beirut: Dar al-M'arifah, 1979.

Ghazzali, Imam. Ihya al-Ulum al Din, Tr. English, Fazlul Karim. New Delhi: Islamic Book Services 1995

Ibn Taimiyah, Al-Hisbah, fi al Islam Tr. English Muhtar Holland ed. Khurishid Ahmad. The Islamic foundation, 1982.

Ibn Khaldun, Muqaddimah (An Introduction to History, Tr. English, Franz Rosenthal, ed. N J Dawood. London: Rout ledge and Paul, 1967.

Shah Wali Allah, Hujjat Allah al Baligah, Vol.2. Beirut, Dar al Fikr. 